\title{
Evidence of Municipal Awareness as a Construct for Enhancing Citizen Satisfaction in Municipal Council of Malaysia
}

\author{
Muhammad Umar Bello ${ }^{1}$, David Martin @ Daud Juanil ${ }^{2}$, Rozilah Kasim ${ }^{2}$, \\ Muhammad Najib Razali ${ }^{3}$, Yunos Ngadiman ${ }^{2}$, Talib Bon ${ }^{2}$
}

${ }^{1}$ Abubakar Tafawa Balewa University

Tawafa Belewa Way, P. M. B. 0248, Bauchi, 740272, Nigeria

${ }^{2}$ Universiti Tun Hussein Onn Malaysia

101 Parit Raja, Batu Pahat, Johor, 86400, Malaysia

${ }^{3}$ Universiti Teknologi Malaysia

Sultan Ibrahim Chancellery Building, Johor Bahru, 81310, Malaysia

DOI: $10.22178 /$ pos.31-2

JEL Classification: L85, R3

Received 03.11.2017

Accepted 10.01.2018

Published online

25.02.2018

Corresponding Author: Muhammad Umar Bello, mubello78@gmail.com

(C) 2018 The Authors. This article is licensed under a Creative Commons Attribution 4.0 License (c) (1)

\begin{abstract}
This research study critically analysed the existing literature on municipal awareness relevancy of Municipal councils' service delivery for the purpose of enhancing citizen satisfaction. The purpose of the study is the investigation of citizen satisfaction level of municipal services. Analysis of the existing literature on the relationship between municipal awareness and citizen satisfaction. The Material and methods were carried out using secondary data and were meticulously and critically analysed to come up with reliable results. The study shows the relevancy of the public awareness, citizen satisfaction and municipal council performance in Malaysia. It is evident in the research that citizen consent is important before municipal services should be provided in the local community. The research study highlighted many discrepancies in many kinds of literature related to the existing research study, the evidence-based analysis was carried out to buttress importance and significance of the related study to the research work. The literature was reviewed to ascertain the current happening in the area of local government service delivery. The study shows that many municipal councils in Malaysia provide adequate and satisfactory services to their citizens'. The study also revealed that municipal council plays an important role in citizen awareness of municipal service delivery. The study concludes that municipal service delivery can be enhanced through citizen awareness campaign, to sensitise the local community on various aspects of service delivery including maintenance of the facilities provided. The study also concludes that Municipal councils lack awareness section affects their performance in service delivery process. The study recommends that Municipal councils officials need to be consulted the citizen for their needs and wants; awareness campaign needs to be regularly carried out to maintain cordial relationship between Municipal councils and their citizen; it is also recommended that municipal services should be delivered the needed services by the local inhabitants' after duly consultation.
\end{abstract}

Keywords: municipal awareness; municipal councils; service delivery; local community; service quality.

\section{INTRODUCTION}

Local governments are observed as foundation for overall rural and semi-urban development $[23,45]$. The position of local governments cannot be over accentuated it's stem from increasing role in local community development and maintainable services $[53,96]$. Nevertheless, effective local government has been recognized as indis- pensable in meeting the Sustainable Development Goals, (SDGs) which entails a tougher role of local governments and municipalities in local development $[15,34,63]$. These includes means of financing local authorities and encouraging citizen awareness of local activities in order to foster transparency, accountability and responsiveness of local authorities, and in turn, increased citizen satisfaction with municipal ser- 
vice and results [20,76]. Within this contextual, there is continue advocacy of enlighten local individuals on local government service delivery and other matters to foster their satisfaction [37, 58]. Authors [75] stated that there is amendment in focus transformed the attention towards the refinements of local communities and citizens and the significance of their engagement in local affairs and service assessment. The role of local government is essential for enhancing municipal services, in that municipal councils are the connecting level of government to citizens and their collaborations and outcomes have significant impacts on citizen's daily survival $[39,99]$.

In other word, citizen awareness and engagement of municipal activities and affairs are importance instruments for aligning municipal development outcomes with the needs and wants of local people [24, 54]. Citizens' awareness of municipal activities', might enhanced citizen support for municipal service delivery. Local government service results mainly signified by municipal services are often constrained by the lack of knowledge about the local processes and procedures among the public [10, 64]. Municipal awareness and enlightenment plays a significant role in citizen attitude toward the local service delivery, performance measurement of local governments activities can be ascertained based on the citizen awareness $[9,46]$. In this regards, how the local community respond to the local authorities' demand showcase the level of local government development attainment [18, 38, 47]. Whereas, well-designed social checklist instruments and positive citizens' perception on the level service delivery are critical for effective municipal performance.

Municipal awareness is of categories; political awareness, regulation awareness, environmental awareness, planning awareness and civic awareness $[28,100]$. All these categories of awareness's have a positive impact on human development and service delivery [74, 90]. Citizen awareness of local government activities and operations through media interventions, public campaigns and forums can promote the capacity of citizens to advocate for their concerned interests and hold local officials accountable for their ill-decisions and activities [30, 92]. Increasing citizen awareness of municipal matters is an effective tool for promoting citizens' engagement and improving people's life and service delivery $[31,57]$. According to [44] rapid human development has a significant effects on municipal de- velopment of an area. Local government served as a catalyst of fuel in the overall development of the world economical ideologies and technological advancement have been forcing public sector to transform their leadership in order to become more responsive and competitive. These statements accentuate that effective leadership has a great chances for enhancement of municipal awareness together with citizen satisfaction for service delivery process in local government administration $[24,25,81]$. Adjustment on the ways in which governments are conducting affairs of the local government service delivery to the ever-changing demands of local community as well as to address the inequalities of the past decades administration $[68,83,91]$.

Moreover, local government needs to change from a merely institutional entity to a more developmental organization. Machinery to achieve these objectives are not embedded and in the external establishment sphere (public-private partnerships and small, medium and micro enterprises), but also in the guidelines and conditions of service, and the quality of local authorities' staffs and sustainability of the working environment. More again, a municipality is an indispensable foundation in the local level through the numerous services it provides for local inhabitants; and through its direct communication with citizens within its land mass jurisdiction. Author [10] stress that appointment of citizens in local government service delivery development kindles local authorities to take care and efforts on commencing more ambitious plans for citizen participation and growing public access to municipal services.

Furthermore, municipal awareness as a mechanisms for citizen satisfaction was acknowledge by [64]. Citizen satisfaction can be reached when the local inhabitants are aware of affairs of the LA's. Authors $[80,103]$ highlights the importance of citizen interaction and community involvement in the management and the evaluation of local programs and activities to avoid random municipal planning and implementation that would result in undesirable local outcome.

Citizen lack of awareness of the administration of local government is the major hindrance to the development of the local government areas and the inhabitants [27, 36, 97]. Responsiveness of citizen towards the local authorities' service delivery are determined by the level of citizen awareness [10,17, 29, 86],citizen satisfaction in Malaysian public sector were given attention es- 
pecially in local authorities' [51], local authorities inhabitants need and wants are attended unsatisfactorily [89] and [32]. Awareness of citizen on the outcome of local authorities' performance outcome may foster cordial understanding. Lack of government commitment towards satisfying local government inhabitants necessitated this study. Creation and establishment of required information can empower local authority with benefits of citizen compliance of their regulations $[10,103]$ and $[22,101]$, against this background awareness of citizen on the performance of local authorities in many countries of the world are based on the seriousness of the government official to enlighten their citizens. Thus, one of the exceptional issues of local authority in Malaysia is that there is no adequate information channel to the citizens. Furthermore, many interests of the citizens are not fully represented in the higher level of decision making of the local councils. In some cases, there is strong political interference in local authorities that affects their actions and decisions.

Many researches has shown that there are various factors impart in creating citizen awareness, satisfaction and sense of belongingness toward brands of any kind but sometimes customers themselves are unaware of the reasons for the brand preferences [40]. In the contemporary time the only constant agent is change. Municipal councils positive change towards advancement of service delivery and information dissemination among the inhabitants enhance the Municipal councils position in terms of provisioning of municipal services. Author [69] assertion is that local government areas are created to solve rural developmental problems and to provide services at satisfactory level. Services such as street sweeping, grass cutting, parking space provisioning etc. are required to be provided and maintained by both the Municipal councils and the citizens' $[41,67]$, With the marvellous increase in population connected a municipality [10], Municipal councils are the bedrock of development of local people and monitoring wing of social justice $[11,12,13,51,97]$.

Objective of the study are:

- to explore the citizen satisfaction level in the local council in Malaysia;

- to analysed the existing literatures on citizen satisfaction;

- to recommend the possible way of improving citizen satisfaction in the local council in Malaysia.

\section{LITERATURES REVIEW}

There are limited literatures on citizen awareness for enhancing citizen satisfaction of municipal service delivery. This study tries to highlight the important of citizen awareness in local government service delivery.

\section{Citizen awareness}

Citizen awareness is very important concepts because it involved understanding and participation of citizen [10,95]. Citizen awareness have been characterized as having ties to the need and wants to the developmental services within their local territory $[16,59,98]$. Citizen were concerned about their local community development and this give them a deep awareness of local government administration appreciation for services needed, and sense of responsibility and participation as stakeholder [56]. The awareness of this concept was expressed by mobilizations in favour of municipal service development [62, 87]. Meanwhile, the councils of local government, civil society organizations, political parties [and] donor agencies all participate in the preparation of village/district profiles, preparation of Periodic Plans, and determination of development priorities, an assessment of the people's present information literacy capabilities is crucial $[1,2,3$, 43].

More again, author [42] suggested that the concepts of public awareness is encompasses behavioural and psychological dimensions that will enable citizen perceptions to determines the performance of local government service delivery. Citizen awareness or Civic awareness is fragment of a constant interaction process between the local authorities, inhabitants and organized civil society. This awareness is Municipal councils classified in terms of the combination of all the community organizations, taking the form and status of social partners through social work, education, public engagement, and the values of basic rights.

\section{Political awareness}

Political awareness are means of citizen understanding of political affairs of their locality, the headship of local government was charge to create resources of public enlightenment towards the municipal process of service delivery $[4,5,6]$. Management of local government expressively 
should be keen in obliging any policy that will improve the process of municipal service delivery $[50,51]$. Creation of mechanism to enlighten the inhabitants on issues related to their life and wellbeing is the main function of local government officials. Political awareness by the nationals' and peoples enable them understand their condition and direction of the local council. Criticisms and grievances' can be channelled properly to the local government $[21,88]$. Many scholars linked citizens' satisfaction with the awareness of the local communities on the services delivered and their expectations on the performance of the local government $[60,66,78,93]$.

\section{Maintenance awareness}

The bounteousness of 21st century industrial tycoons bestowed many of our finest cities with far-reaching formal and semi-formal facilities and uncountable parks, all of which require ongoing maintenance. Similar-Facilities provided by the local council need to be preserved and maintained by both the producers and the users, before this can be done properly mutual understanding must be sustained between the providers and the users. Municipal branding and the development of local community plays a significant role in urban development [72]. Nevertheless, in particular these services also have a reverse side-effect in regard to urban sustainability in the absence of users' awareness.

\section{Citizen satisfaction}

Around 1989 Sweden became the first country in the world to established standardized cross company and cross industry methodology of measuring customer satisfaction and customer loyalty [84]. This general and national measurement gadget for customer satisfaction and customer loyalty is called the Swedish Customer Satisfaction Barometer (SCSB). Satisfaction of municipal services is one of the major evaluation of Municipal councils service delivery performance [14]. Municipal councils performance must commiserate with citizen satisfaction of municipal services provisioned by local council, satisfaction of citizenry should be main target of local government officials. To makes a meaningful development within the demarcation of local council, the needs and wants of the inhabitants' fulfilment represents the activeness of the local coun- cils. In Malaysia the position of local councils allow them to take the responsibility of providing services to the local community [55, 82, 85, 94]. If the municipal services delivered by the local councils are perceived as poor, the future of good governance and professional images of this local councils will be at stake [85]. Malaysian federal government set aside large sum of money for local community development services [73].

The Table 1 above shows different research on local government service delivery with different dimension of service delivery. The studies revealed different outcomes of the researches; study 1 revealed that there are a number of explicit uncertainties that affect building maintenance planning making more detailed long-term plans less meaningful. Research 2, 3, 4 and 5 focused on citizen satisfaction of local government service delivery.

\section{MATERIAL AND METHODS}

Data used in this research paper were extracted from secondary sources of data which comprised of textbooks, articles, thesis and statutory documents. The data were critically reviewed to ascertain the current happening in the area of local government service delivery. It must be emphasise here that the method adopted for data collection in this study is a literature review analysis. Upon extracting data from the review, inferences will be drawn on municipal awareness for enhancing citizen satisfaction of municipal services in municipal council in Malaysia. Evidence analysis was drawn from previous studies.

\section{RESULT AND DISCUSSION}

The result of the research study was revealed that municipal council in Malaysia provide adequate and satisfactory services to their citizens'. The result of this research study support the work of $[49,61]$. The authenticity of this research work is verified thoroughly, and the results vindicated that similar research come to agree with the conclusion of the results of this research work in many respects. The author [10] that indicate that awareness of citizen is integral part of process of assessing government performance, this also agree with the final result of this research work. Municipal services quality is determined by the quality of the inhabitants' life. 
Table 1 - Evidence based analysis of related literatures on the study

\begin{tabular}{|c|c|c|c|c|}
\hline No & Author & Title & Findings & Observation \\
\hline 1 & Almarshad S. & $\begin{array}{l}\text { Municipal awareness and } \\
\text { citizen satisfaction: The } \\
\text { case of the Northern } \\
\text { Borders in Saudi Arabia }\end{array}$ & $\begin{array}{l}\text { The results of the study revealed } \\
\text { positive relationship between } \\
\text { municipal awareness and citizen } \\
\text { satisfaction }\end{array}$ & $\begin{array}{l}\text { The study is failed to assess } \\
\text { the level of citizen satisfaction } \\
\text { of municipal services provided } \\
\text { by the local government }\end{array}$ \\
\hline 2 & Osman M. & $\begin{array}{l}\text { An assessment of local } \\
\text { authority performance in } \\
\text { delivering their services: } \\
\text { Case study of Ipoh City } \\
\text { Council }\end{array}$ & $\begin{array}{l}\text { Issue identified were the lack of } \\
\text { transparency, delays in services, } \\
\text { lack of customer service courtesy } \\
\text { and unaccountable practices that } \\
\text { obstructs governmental } \\
\text { effectiveness and creates } \\
\text { numerous complaints among } \\
\text { public and respondents }\end{array}$ & $\begin{array}{l}\text { The study is did not give } \\
\text { emphasis on customer chance } \\
\text { to participates on service } \\
\text { delivery }\end{array}$ \\
\hline 3 & Mansor N. & $\begin{array}{l}\text { Customers' Satisfaction } \\
\text { towards Counter Service } \\
\text { of Local Authority in } \\
\text { Terengganu, Malaysia } \\
\end{array}$ & $\begin{array}{l}\text { Findings revealed that, there were } \\
\text { significant relationships between } \\
\text { the selected dimensions as to the } \\
\text { main theme of the study }\end{array}$ & $\begin{array}{l}\text { The study is limited to counter } \\
\text { service alone and did not treat } \\
\text { other aspects of service } \\
\text { delivery }\end{array}$ \\
\hline 4 & Donnelly M. & $\begin{array}{l}\text { Measuring service quality } \\
\text { in Malaysian local } \\
\text { government: the } \\
\text { SERVQUAL approach }\end{array}$ & $\begin{array}{l}\text { Findings of the studies revealed } \\
\text { that, service provider usually over- } \\
\text { estimate service user expectation }\end{array}$ & $\begin{array}{l}\text { The research study is limited } \\
\text { because it consider only the } \\
\text { users' expectation not their } \\
\text { attitude towards service } \\
\text { provided }\end{array}$ \\
\hline 5 & Mokhlis S. & $\begin{array}{l}\text { Municipal Service Quality } \\
\text { and Citizen Satisfaction in } \\
\text { Southern Thailand }\end{array}$ & $\begin{array}{l}\text { Findings of the study provide } \\
\text { various important administrative } \\
\text { implications for municipal } \\
\text { councils by present them practical } \\
\text { guidelines to improve quality } \\
\text { services that would increase } \\
\text { citizen satisfaction }\end{array}$ & $\begin{array}{l}\text { The research study is limited } \\
\text { because customers consent } \\
\text { were not seek before service is } \\
\text { provided }\end{array}$ \\
\hline 6 & Rahman M. S. & $\begin{array}{l}\text { Service Quality, } \\
\text { Corporate Image And } \\
\text { Customer's Satisfaction } \\
\text { Towards Customers } \\
\text { Perception: An } \\
\text { Exploratory Study On } \\
\text { Telecom Customers in } \\
\text { Bangladesh }\end{array}$ & Quantitative & $\begin{array}{l}\text { The study provided empirical } \\
\text { evidence for the development } \\
\text { of customer's perception } \\
\text { towards the mobile phone } \\
\text { operators involving corporate } \\
\text { image, customer's satisfaction, } \\
\text { and service quality in } \\
\text { Bangladesh }\end{array}$ \\
\hline 7 & Zakaria Z. & $\begin{array}{l}\text { Historical of Customer } \\
\text { Satisfaction in Municipal } \\
\text { Services }\end{array}$ & Quantitative & $\begin{array}{l}\text { The study shows that citizen } \\
\text { satisfaction is low due to the } \\
\text { constraints in much municipal } \\
\text { council }\end{array}$ \\
\hline 8 & Momeni M. & $\begin{array}{l}\text { Investigating the Degree } \\
\text { of Satisfaction with } \\
\text { Municipal Managers: A } \\
\text { Case Study in Iran }\end{array}$ & Quantitative & $\begin{array}{l}\text { The study shows that citizen } \\
\text { satisfaction of municipal } \\
\text { services in four (4) study area } \\
\text { is low. It accorded that the } \\
\text { high participation the higher } \\
\text { citizen satisfaction attained } \\
\end{array}$ \\
\hline 9 & Akgul D. & $\begin{array}{l}\text { Measuring the } \\
\text { Satisfaction of Citizens for } \\
\text { the Services given by the } \\
\text { Municipality: The Case of } \\
\text { Kirşehir Municipality }\end{array}$ & Quantitative & $\begin{array}{l}\text { The study shows that citizen } \\
\text { satisfaction is at lower level }\end{array}$ \\
\hline 10 & Okunola 0. & $\begin{array}{l}\text { Users' experience of e- } \\
\text { government services: a } \\
\text { case study based on the } \\
\text { Nigeria immigration } \\
\text { service }\end{array}$ & Quantitative & $\begin{array}{l}\text { The shows that e-government } \\
\text { services are not co-opted as it } \\
\text { was in adopted in developed } \\
\text { countries }\end{array}$ \\
\hline
\end{tabular}


The resource [48] also agree with the finding of this research work. This particular study did not agree with the research of [52] that emphasised that community participation is only the key indicators for satisfactory service delivery because generally factors responsible for citizen satisfaction are enormous and depends on the location $[26,65]$. Different studies vindicated that municipal awareness is very significant in public service delivery $[8,19,77]$. It is also agree with assertion of working documents [35] and [71]. Conversely, all researches vindicated that studies on service delivery are accumulated with problems one way or the order [77].

\section{CONCLUSION}

This research work concluded that municipal services delivery can be enhance through citizen awareness campaign, to sensitise the local community on various aspects of service delivery including maintenance of the facilities provided. It is also concluding that Municipal council's lack of awareness section affects their performance in service delivery. The study also concludes that municipal awareness is among the key items in determining the citizen satisfaction in both urban and rural areas. It was evident that citizen needs a kind of sensitization to understand the process and the durability of the services provisioned. The study recommended that Municipal councils officials need to consults the citizen for their needs and wants; awareness campaign need to be regularly carried out to maintain cordial relationship between Municipal councils and their citizen; it is also recommended that municipal services should be delivered after duly consultation with the local communities.

\section{ACKNOWLEDGE}

The authors are grateful to the previous literature research that has been made in any anonymous journal arbitrators related to municipal service delivery and citizen satisfaction. The authors also show their indebtedness to NEEDS ASSESSMENT PROGRAM from ATBU Bauchi who sponsor the researcher for PhD program in UTHM and Office for Research, Innovation, Commercialization and Consultancy Management (ORICC) UTHM, Batu Pahat, Johor, Malaysia that appoint the researcher as Graduate Research Assistant.

\section{REFERENCES}

1. Aagesen, G. (2012). Multi-channel Provisioning of Public Services (Doctoral thesis). Retrieved from http://brage.bibsys.no/xmlui/handle/11250/252859

2. Abe, T., \& Monisola, O. J. (2014). Citizen Participation and Service Delivery at the Local Government Level: A Case of Ise/Orun Local Government in Ekiti State, Nigeria. Journal of Law, Policy and Globalization, 27, 102-110.

3. Abid, A. (2004). Information literacy for lifelong learning. In World Library and Information Congress: 70th IFLA General Conference and Council, 22-27 August 2004, Buenos Aires, Argentina. Retrieved from http://www.ifla.org/IV/ifla70/papers/116e-Abid.pdf

4. Adeyemi, O. (2013). Local Government and the Challenges of Service Delivery: the Nigeria Experience. Journal of Sustainable Development in Africa, 15(7), 84-98.

5. Agba, M. S., Akwara, A. F., \& Idu, A. (2013). Local Government and Social Service Delivery in Nigeria: A Content Analysis. Academic Journal of Interdisciplinary Studies, 2(2), 455-462. doi: 10.5901/ajis.2013.v2n2p455

6. Aijaz, R. (2007). Challenges for Urban Local Governments in India. Retrieved from http://eprints.lse.ac.uk/25190/1/ARCWorkingPaper19RumiAijaz2007.pdf

7. Akgul, D. (2012). Measuring the Satisfaction of Citizens for the Services given by the Municipality: The Case of Kirşehir Municipality. Procedia - Social and Behavioral Sciences, 62, 555-560. doi: 10.1016/j.sbspro.2012.09.092

8. Akinloye Akinboade, O., Chanceline Kinfack, E., \& Putuma Mokwena, M. (2012). An analysis of citizen satisfaction with public service delivery in the Sedibeng district municipality of South Africa. International Journal of Social Economics, 39(3), 182-199. doi: 10.1108/03068291211199350 
9. Almarshad, A. I. A., \& Klein, A. C. (1991). A model for waterside oxidation of Zircaloy fuel cladding in pressurized water reactors. Journal of Nuclear Materials, 183(3), 186-194. doi: 10.1016/00223115(91)90487-r

10. Almarshad, S. O. (2015). Municipal awareness and citizen satisfaction: The case of the Northern Borders in Saudi Arabia. International Review of Management and Marketing, 5(2), 94-101.

11. Amin, M., \& Isa, Z. (2008). An examination of the relationship between service quality perception and customer satisfaction: A SEM approach towards Malaysian Islamic banking. International Journal of Islamic and Middle Eastern Finance and Management, 1(3), 191-209. doi: 10.1108/17538390810901131

12. Andrews, R., Boyne, G. A., Law, J., \& Walker, R. M. (2005). External constraints on local service standards: The case of comprehensive performance assessment in English local government. Public Administration, 83(3), 639-656. doi: 10.1111/j.0033-3298.2005.00466.x

13. Antuono, L., Meeks, C., Miller, M. K., \& Watchou, J. R. (2006). Evaluating NGO Service Delivery in South Asia: Lessons for Afghanistan. Retrieved from

http://www.lafollette.wisc.edu/images/publications/workshops/2006-servicedelivery.pdf

14. Anwer, M. A., Esichaikul V., Rehman, M., \& Anjum M. (2016). E-government services evaluation from citizen satisfaction perspective. Transforming Government: People, Process and Policy, 10(1), 139-167. doi: 10.1108/TG-03-2015-0017

15. Appleyard, L. (2011). Community Development Finance Institutions (CDFIs): Geographies of financial inclusion in the US and UK. Geoforum, 42(2), 250-258. doi:

10.1016/j.geoforum.2010.09.004

16. Bache, I. (2013). Measuring quality of life for public policy: an idea whose time has come? Agendasetting dynamics in the European Union. Journal of European Public Policy, 20(1), 21-38. doi: 10.1080/13501763.2012.699658

17. Barnes, M. (1999). Users as citizens: collective action and the local governance of welfare. Social Policy and Administration, 33(1), 73-90. doi: 10.1111/1467-9515.00132

18. Bello, M. U., Juani, D. M. D., \& Kasim, R. (2017). Municipal Awareness as a Tool for Enhancing Citizen Satisfaction in Municipal Councils of Malaysia. European Journal of Social Sciences Studies, 2(5), 109-116.

19. Besley, T., \& Ghatak, M. (2007). Reforming Public Service Delivery. Journal of African Economies, 16, 127-156. doi: 10.1093/jae/ejm026

20. Bin, Y., \& Quan, L. (2012). Construction Financing Problem of Local Government in China. Physics Procedia, 24, 1773-1780. doi: 10.1016/j.phpro.2012.02.261

21. Blaug, R., Horner, L., \& Lekhi, R. (2006). Public Value, Citizen Expectations and User Commitment: A Literature Review. Retrieved from https://www.researchgate.net/publication/253726604_Public_value_citizen_expectations_and_ user_commitment

22. Borins, S. (2012). Innovation in business and government: Looking forward. Retrieved from https://coombs-forum.crawford.anu.edu.au/publication/hc-coombs-policyforum/2493/innovation-business-and-government-looking-forward

23. Borsekova, K., Vanova, A., \& Vitalisova, K. (2016). The Power of Communities in Smart Urban Development. Procedia - Social and Behavioral Sciences, 223, 51-57. doi: 10.1016/j.sbspro.2016.05.289

24. Breitbarth, T., Mitchell, R., \& Lawson, R. (2010). Service performance measurement in a New Zealand local government organization. Business Horizons, 53(4), 397-403. doi:

10.1016/j.bushor.2010.03.004 
25. Buis, H. (2009). The role of local government associations in increasing the effectiveness of city-tocity cooperation. Habitat International, 33(2), 190-194. doi: 10.1016/j.habitatint.2008.10.017

26. Byrne, P. (1994). The Review of Local Government. Property Management, 12(3), 5-8. doi: 10.1108/02637479410064214

27. Callahan, K. (2002). The utilization and effectiveness of citizen advisory committees in the budget process of local governments. Journal of Public Budgeting, Accounting and Financial Management, 14(2), 295-319.

28. Carrel, H. (2009). Disputing legal privilege: civic relations with the Church in late medieval England. Journal of Medieval History, 35(3), 279-296. doi: 10.1016/j.jmedhist.2009.06.001

29. Darison, A.-H. B. (2011, September). Enhancing local government revenue mobilization through the use of information communication technology: a case-study of Accra Metropolitant Assembly (Master thesis). Retrieved from

http://ir.knust.edu.gh/xmlui/bitstream/handle/123456789/2156/DARISON\%27S\%20thesis.p df? sequence $=1$

30. Dee, T. S. (2010). Education and Civic Engagement. In P. Peterson, E. Baker, \& B. McGaw (Eds.), International Encyclopedia of Education (3rd ed.) (pp. 235-238). Oxford: Elsevier.

31. Deng, W.-S., Lin, Y.-C., \& Gong, J. (2012). A smooth coefficient quantile regression approach to the social capital-economic growth nexus. Economic Modelling, 29(2), 185-197. doi:

10.1016/j.econmod.2011.09.008

32. Dewulf, G., \& Meel, J. (2002). User participation and the role of information and communication technology. Journal of Corporate Real Estate, 4(3), 237-247. doi: 10.1108/14630010210811868

33. Donnelly, M., Wisniewski, M., Dalrymple, J., F., \& Curry, A. C. (1995). Measuring service quality in Malaysian local government: the SERVQUAL approach. International Journal of Public Sector Management, 8(7), 15-20. doi: 10.1108/09513559510103157

34. Dupuy, K. E. (2014). Community development requirements in mining laws. The Extractive Industries and Society, 1(2), 200-215. doi: 10.1016/j.exis.2014.04.007

35. Duroy, Q. M. (2005). The Determinants of Environment Awareness and Behavior. Retrieved from http://www.economics.rpi.edu/workingpapers/rpi0501.pdf

36. Ebdon, C. (2002). Beyond the public hearing: citizen participation in the local government budget, process. Journal of Public Budgeting, Accountability and Financial Management, 14(2), 273-294.

37. Evans, E. (2009). A framework for development? The growing role of UK local government in international development. Habitat International, 33(2), 141-148. doi:

10.1016/j.habitatint.2008.10.010

38. Galiński, P. (2015). Determinants of Debt Limits in Local Governments: Case of Poland. Procedia Social and Behavioral Sciences, 213, 376-382. doi: 10.1016/j.sbspro.2015.11.554

39. Hanafiah, M. H., Jamaluddin, M. R., \& Zulkifly, M. I. (2013). Local Community Attitude and Support towards Tourism Development in Tioman Island, Malaysia. Procedia - Social and Behavioral Sciences, 105, 792-800. doi: 10.1016/j.sbspro.2013.11.082

40. Hanif, M., Hafeez, S., \& Riaz, A. (2010). Factors Affecting Customer Satisfaction. International Resource Journal of Finance and Economics, 60, 44-52.

41. Hilgers, D., \& Ihl, C. (2010). Citizensourcing: Applying the Concept of Open Innovation to the Public Sector. The International Journal of Public Participation, 4(1), 67-88.

42. Holmes, B. (2011, July 22). Citizen's engagement in policymaking and the design of public services. Retrieved from

http://www.aph.gov.au/About_Parliament/Parliamentary_Departments/Parliamentary_Library /pubs/rp/rp1112/12rp01

43. Horton, F., W. (Ed.) (2013). Overview of Information Literacy Resources Worldwide. Paris: UNESCO. 
44. Hou, J., Walsh, P. P., \& Zhang, J. (2015). The dynamics of Human Development Index. The Social Science Journal, 52(3), 331-347. doi: 10.1016/j.soscij.2014.07.003

45. Ibrahim, A. A. A. M. (2012). A Decision Making Approach for Prioritizing Local Communities' Development Investments. Procedia - Social and Behavioral Sciences, 68, 649-660. doi: 10.1016/j.sbspro.2012.12.256

46. Ihlanfeldt, K., \& Mayock, T. (2015). Foreclosures and local government budgets. Regional Science and Urban Economics, 53, 135-147. doi: 10.1016/j.regsciurbeco.2015.05.007

47. Inman, J., \& Picton, H. (2012). Finding Official British Information. N. d.: Chandos Publishing.

48. Ireland Ministry for the Environment, Heritage and Local Government (2004, January). Delivering Value for People Service Indicators in Local Authorities. Retrieved from

https://www.yumpu.com/en/document/view/17734537/delivering-value-for-people-serviceindicators-in-local-authorities/3

49. Kaliannan, A., Puteh, F., \& Dorasamy, M. (2014). Measuring service quality in Malaysian local government: the SERVQUAL approach. Retrieved from http://www.kmice.cms.net.my/ProcKMICe/KMICe2014/PDF/PID16.pdf

50. Kernaghan, K. (2015). Serving seniors: Innovation and public sector service delivery. The Innovation Journal, 20(2), 1-18.

51. Khalid, S. A. (2010). Improving the Service Delivery: A case Study of Local Authority in Malaysia. Global Business Review, 11(1), 65-77. doi: 10.1177/097215090901100104

52. Kugonza, S., \& Mukobi, R. (2015). Public participation in services delivery projects in Buikwe District Local Government Uganda. Commonwealth Journal of Local Governance, 18, 127-147. doi: 10.5130/cjlg.v0i18.4846

53. Labonne, J., \& Chase, R. S. (2011). Do community-driven development projects enhance social capital? Evidence from the Philippines. Journal of Development Economics, 96(2), 348-358. doi: 10.1016/j.jdeveco.2010.08.016

54. Lee, T. H. (2013). Influence analysis of community resident support for sustainable tourism development. Tourism Management, 34, 37-46. doi: 10.1016/j.tourman.2012.03.007

55. Mansor, N., \& Razali, C. (2010). Customers' Satisfaction towards Counter Service of Local Authority in Terengganu, Malaysia. Asian Social Science, 6(8), 197-208. doi: 10.5539/ass.v6n8p197

56. Mccann, E., Sullivan, S., Erickson, D., \& Young, R. (1997). Environmental Awareness, Economic Orientation, and Farming Practices: A Comparison of Organic and Conventional Farmers. Environmental Management, 21(5), 747-758. doi: 10.1007/s002679900064

57. McDermott, P. (2010). Building open government. Government Information Quarterly, 27(4), 401413. doi: 10.1016/j.giq.2010.07.002

58. Mey, F., Diesendorf, M., \& MacGill, I. (2016). Can local government play a greater role for community renewable energy? A case study from Australia. Energy Research \& Social Science, 21, 33-43. doi: 10.1016/j.erss.2016.06.019

59. Milinthajinda, P. (1999). Environmental Awareness of Municipality Members in Phetchaburi Province (Master thesis). Bangkok: Kasetsart University.

60. Mishler, W., \& Rose, I. (2001). What are the origins of political trust? Testing institutional and cultural theories in post-communist societies. Comparative Political Studies, 34(1), 30-62. doi: 10.1177/0010414001034001002

61. Mokhlis, S., Aleesa, Y, \& Mamat, I. (2011). Municipal Service Quality and Citizen Satisfaction in Southern Thailand. Journal of Public Administration and Governance, 1(1), 122-137. doi: 10.5296/jpag.v1i1.717

62. Momeni, M., \& Asadi Astaraki, M. (2014). Investigating the Degree of Satisfaction with Municipal Managers: A Case Study in Iran. Asian Social Science, 10(16). doi: 10.5539/ass.v10n16p42 
63. Moradei, G. (2014). 10 Years of community design - 8-9 April 2013, Alicante, Spain. World Patent Information, 36, 49-50. doi: 10.1016/j.wpi.2013.11.011

64. Motawa, I., \& Almarshad, A. (2013). A knowledge-based BIM system for building maintenance. Automation in Construction, 29, 173-182. doi: 10.1016/j.autcon.2012.09.008

65. Muhammad, Z., Masron, T., \& Majid, A. A. (2015). Local Government Service Efficiency: Public Participation Matters. International Journal of Social Science and Humanity, 5(10), 827-831. doi: 10.7763/ijssh.2015.v5.565

66. Newton, K. (2001). Trust, social capital, civil society, and democracy. International Political Science Review, 22(2), 201-214. doi: 10.1177/0192512101222004

67. Nyqvist, M., Walque, D., \& Svensson, J. (2014, August). Information is Power: Experimental Evidence on the Long-Run Impact of Community Based Monitoring. Retrieved from http://documents.worldbank.org/curated/en/739811468318587268/pdf/WPS7015.pdf

68. O'Mullane, M., \& Quinlivan, A. (2012). Health Impact Assessment (HIA) in Ireland and the role of local government. Environmental Impact Assessment Review, 32(1), 181-186. doi: 10.1016/j.eiar.2011.08.004

69. Ofoeze, H. G. A. (1999). Local government and development administration: Issues and cases. In O. Okereke (Ed.), Development Administration in Nigeria: Issues and Strategies (pp. 115-129). N. d.: Concave Publishers.

70. Okunola, O. M. (2015). Users' experience of e-government services: a case study based on the Nigeria immigration service (Doctoral thesis). Retrieved from https://espace.mmu.ac.uk/612199/

71. Olsen, J. P. (2003). Citizens, public administration and the search for theoretical foundations. Retrieved from http://www.sv.uio.no/arena/english/research/publications/arena-workingpapers/2001-2010/2003/wp03_20.pdf

72. Osman, M. M., Jusoh, N. N., Bachok, S., \& Bakri, N. I. (2014). An assessment of local authority performance in delivering their services: Case study of Ipoh City Council. Journal of Architecture, Planning \& Construction Management, 4(2), 58-76.

73. Osman, M., Bakri, I., Bachok, S., Ibrahim, M., \& Mohamed, M. (2015). Assessing social welfare department service delivery system towards vulnerable and disadvantages group in Malaysia: a case study of Perak. Procedia Environmental Sciences, 28, 418-426. doi:

10.1016/j.proenv.2015.07.051

74. Özcan, B., \& Bjørnskov, C. (2011). Social trust and human development. The Journal of SocioEconomics, 40(6), 753-762. doi: 10.1016/j.socec.2011.08.007

75. Peters, M., Fudge, S., \& Sinclair, P. (2010). Mobilising community action towards a low-carbon future: Opportunities and challenges for local government in the UK. Energy Policy, 38(12), 7596-7603. doi: 10.1016/j.enpol.2010.01.044

76. Pinnuck, M., \& Potter, B. N. (2009). The quality and conservatism of the accounting earnings of local governments. Journal of Accounting and Public Policy, 28(6), 525-540. doi:

10.1016/j.jaccpubpol.2009.08.002

77. PricewaterhouseCooper. (2007).The Road Ahead for Public Service Delivery. Retrieved from https://www.pwc.com/gx/en/psrc/pdf/the_road_ahead_for_public_service_delivery.pdf

78. Putnam, R., Leonardi, R., \& Nanetti, R. (1993). Making Democracy Work: Civic Traditions in Modern Italy. Princeton: Princeton University Press.

79. Rahman, M. S. (2012). Service Quality, Corporate Image And Customer's Satisfaction Towards Customers Perception: An Exploratory Study On Telecom Customers in Bangladesh. Business Intelligence Journal, 5(1), 56-63. 
80. Ramachandra, A., \& Mansor, N. (2014). Sustainability of community engagement - in the hands of stakeholders? Education + Training, 56(7), 588-598. doi: 10.1108/ET-07-2014-0084

81. Reddick, C. G. (2009). The adoption of centralized customer service systems: A survey of local governments. Government Information Quarterly, 26(1), 219-226. doi: 10.1016/j.giq.2008.03.005

82. Rozilah, K., Alkali, M., \& Bala, I. (2014). Assessment of service user's experience on the facilities provision at UTHM Students' Residential Colleges. In 7th International Real Estate Research Symposium, 29-30 April, National Institute of Valuation, Putrajaya (pp. 1-12).

83. Sá, F., Rocha, Á., \& Cota, M. P. (2016). Potential dimensions for a local e-Government services quality model. Telematics and Informatics, 33(2), 270-276. doi: 10.1016/j.tele.2015.08.005

84. Sajid, R. (2013). Measuring Customer Satisfaction and Loyalty in Relation to Online Shopping in Denmark (Master thesis). Retrieved from http://studylib.net/doc/18334526/measuringcustomer-satisfaction-and-loyalty-in-relation-to

85. Samsudin, S., Haron, S., \& Bakar, A. N. (2012). Operational Issues in Malaysian Local Authority: Value of Intermediaries Services toward Client Satisfaction. Procedia - Social and Behavioral Sciences, 68, 844-854. doi: 10.1016/j.sbspro.2012.12.271

86. Sandford, M. (2016). Local government: alternative models of service delivery. Retrieved from http://researchbriefings.files.parliament.uk/documents/SN05950/SN05950.pdf

87. Sayers, R. (2006). Principles of Awareness-Raising for Information Literacy, a case study. Bangkok: UNESCO Bangkok.

88. Shafie, F. (2013). Fm Help Desk: User Complaint System as an Fm Approach for Facilities Management Services in University TUN Hussein Onn Malaysia (UTHM) (Master thesis). Retrieved from http://eprints.uthm.edu.my/6870/1/GIPS_0700.pdf

89. Siddiquee, N. A. (2006). Public management reform in Malaysia: Recent initiatives and experiences. International Journal of Public Sector Management, 19(4), 339-358. doi: 10.1108/09513550610669185

90. Sinha, A., \& Sen, S. (2016). Atmospheric consequences of trade and human development: A case of BRIC countries. Atmospheric Pollution Research, 7(6), 980-989. doi: 10.1016/j.apr.2016.06.003

91. Sourouni, A.-M., Kourlimpinis, G., Mouzakitis, S., \& Askounis, D. (2010). Towards the government transformation: An ontology-based government knowledge repository. Computer Standards \& Interfaces, 32(1-2), 44-53. doi: 10.1016/j.csi.2009.06.002

92. Sovacool, B. K., \& Valentine, S. V. (2010). The socio-political economy of nuclear energy in China and India. Energy, 35(9), 3803-3813. doi: 10.1016/j.energy.2010.05.033

93. Stoner, K. (2002). Local Heroes: The Political Economy of Russian Regional Governance. Princeton: Princeton University Press.

94. Subhan, M., Ghani, A., \& Joarder, M. (2014). Urban community willingness to pay for improved solid waste management in Malaysian municipality: A choice modeling approach. Asian Social Science, 10(18), 122-136. doi: 10.5539/ass.v10n18p122

95. Sureshchandar, G. S., Rajendran, C., \& Anantharaman, R. N. (2002). The relationship between service quality and customer satisfaction: a factor specific approach. Journal of Services Marketing, 16(4), 363-379. doi: 10.1108/08876040210433248

96. Szitar, M.-A. (2014). Learning about Sustainable Community Development. Procedia - Social and Behavioral Sciences, 116, 3462-3466. doi: 10.1016/j.sbspro.2014.01.784

97. Unegbu, V. E. (2013). Perceived Effect of Local Government Knowledge of Citizens Awareness of Local Government Income on its Utilization in Nigeria. Arabian Journal of Business and Management Review(Oman Chapter), 2(10), 40-50. doi: 10.12816/0002332 
98. Wang, I.-M., \& Shieh, C.-J. (2006). The relationship between service quality and customer satisfaction: the example of CJCU library. Journal of Information and Optimization Sciences, 27(1), 193-209. doi: 10.1080/02522667.2006.10699686

99. Whitford, M. (2009). A framework for the development of event public policy: Facilitating regional development. Tourism Management, 30(5), 674-682. doi: 10.1016/j.tourman.2008.10.018

100. Whitlock, A. M. (2017). Teaching about social business: The intersection of economics instruction and civic engagement. The Journal of Social Studies Research, 41(3), 235-242. doi: 10.1016/j.jssr.2016.12.002

101. Wihlman, T. (2014). Innovation in Municipal Welfare Services. Mälardalens högskola: Mälardalen University.

102. Zakaria, Z., Ngah, K., Noordin, N., Sawal, M. Z., \& Hj Hussin, Z. (2012). Historical of Customer Satisfaction in Municipal Services. Retrieved from http://www.ipedr.com/vol28/28ICEMM2012-T10014.pdf

103. Zamzami, Y. (2004). Neighborhood centers in Saudi society and realistic experience futuristic look. Publications Umm Al Qura University, 12(2), 153-167. 